\title{
OSTEOGENESIS AND ANGIOGENESIS: THE POTENTIAL FOR ENGINEERING BONE
}

\author{
J.M. Kanczler*, R.O.C. Oreffo
}

Bone \& Joint Research Group, Centre for Human Development, Stem Cells and Regeneration, Developmental Origins of Health and Disease, Institute of Developmental Sciences, University of Southampton, Southampton, SO16 6YD, U.K.

\begin{abstract}
The repair of large bone defects remains a major clinical orthopaedic challenge. Bone is a highly vascularised tissue reliant on the close spatial and temporal connection between blood vessels and bone cells to maintain skeletal integrity. Angiogenesis thus plays a pivotal role in skeletal development and bone fracture repair. Current procedures to repair bone defects and to provide structural and mechanical support include the use of grafts (autologous, allogeneic) or implants (polymeric or metallic). These approaches face significant limitations due to insufficient supply, potential disease transmission, rejection, cost and the inability to integrate with the surrounding host tissue.

The engineering of bone tissue offers new therapeutic strategies to aid musculoskeletal healing. Various scaffold constructs have been employed in the development of tissue-engineered bone; however, an active blood vessel network is an essential pre-requisite for these to survive and integrate with existing host tissue. Combination therapies of stem cells and polymeric growth factor release scaffolds tailored to promote angiogenesis and osteogenesis are under evaluation and development to actively stimulate bone regeneration. An understanding of the cellular and molecular interactions of blood vessels and bone cells will enhance and aid the successful development of future vascularised bone scaffold constructs, enabling survival and integration of bioengineered bone with the host tissue. The role of angiogenic and osteogenic factors in the adaptive response and interaction of osteoblasts and endothelial cells during the multi step process of bone development and repair will be highlighted in this review, with consideration of how some of these key mechanisms can be combined with new developments in tissue engineering to enable repair and growth of skeletal fractures. Elucidation of the processes of angiogenesis, osteogenesis and tissue engineering strategies offer exciting future therapeutic opportunities for skeletal repair and regeneration in orthopaedics.
\end{abstract}

Key Words: human bone marrow stromal cells, bone tissue regeneration, polylactic acid scaffolds, vascular endothelial growth factor, osteogenesis, angiogenesis, segmental defect.

\section{Introduction}

Skeletal development and fracture repair includes the coordination of multiple events such as migration, differentiation, and activation of multiple cell types and tissues (Colnot et al., 2005). The development of a microvasculature and microcirculation is critical for the homeostasis and regeneration of living bone, without which, the tissue would simply degenerate and die (Schmid et al., 1997). The importance of blood vessels in the formation of the skeleton and in bone repair was documented as early as the 1700s, (Haller, 1763; Hunter, 1794). However, the research into osteogenesis over the next century or so concentrated mainly on the role and function of the osteoblast. In 1963, Trueta published data that revived interest in the functions of the vasculature in osteogenesis proposing that there was a vascular stimulating factor (VSF) which was released at the fracture sites of bone (Trueta, 1963). Recent developments using in vitro and in vivo models of osteogenesis and fracture repair have provided a better understanding of the recruitment nature of the vasculature in skeletal development and repair (Brandi and Collin-Osdoby, 2006).

The vasculature transports oxygen, nutrients, soluble factors and numerous cell types to all tissues in the body. The growth and development of a mature vascular structure is one of the earliest events in organogenesis (Coultas et al., 2005). In mammalian embryonic development, the nascent vascular networks develop by aggregation of de novo forming angioblasts into a primitive vascular plexus (vasculogenesis). This undergoes a complex remodelling process in which sprouting, bridging and growth from existing vessels (angiogenesis) leads to the onset of a functional circulatory system (Jain, 2003).

\footnotetext{
*Address for correspondence:

J.M. Kanczler,

Bone \& Joint Research Group,

Centre for Human Development, Stem Cells and Regeneration,

Institute of Developmental Sciences, DOHaD,

University of Southampton, General Hospital, Southampton SO16 6YD, U.K.

Telephone Number +44 2380798502

FAX Number: +44 2380795255

Email: jk9@soton.ac.uk

URL:www.skeletalstemcells.org
} 
The factors and events that lead to the normal development of the embryonic vasculature are recapitulated during situations of neoangiogenesis in the adult (Carmeliet, 2003). There are a number of factors involved in neoangiogenesis, the main protagonists are; Vascular Endothelial Growth Factor (VEGF), basic Fibroblast Growth Factor (bFGF), various members of the Transforming Growth factor beta (TGF $\beta$ ) family and hypoxia (Hypoxia-inducible transcription factor, HIF). Other factors that have angiogenic properties include the angiopoietins, (Ang-1); hepatocyte growth factor (HGF); Platelet-derived growth factor (PDGF-BB); Insulin-like growth factor family (IGF-1, IGF-2) and the Neurotrophins (NGF) (Madeddu, 2005).

The VEGFs and their corresponding receptors are key regulators in a cascade of molecular and cellular events that ultimately lead to the development of the vascular system, either by vasculogenesis, angiogenesis or in the formation of the lymphatic vascular system. (Tammela et al., 2005; Ferrara and Gerber, 2001; Carmeliet and Collen, 2000; Yancopoulos et al., 2000; Rossant and Howard, 2002). Although VEGF is a critical regulator in physiological angiogenesis it also plays a significant role in skeletal growth (Zelzer et al., 2002; Gerber et al., 1999; Haigh et al., 2000; Ryan et al., 1999) and repair (Street et al., 2002; Chu et al., 2002; Peng et al., 2002).

In the mature established vasculature, the endothelium plays a pivotal role in the maintenance of homeostasis of the surrounding tissue providing the communicative network to neighbouring tissues to respond to requirements as needed. Furthermore, the vasculature provides the necessary factors such as growth factors, hormones, cytokines, chemokines and metabolites needed by the surrounding tissue and acts, when needed, as a barrier to limit the movement of molecules and cells. Signals and attractant factors expressed on the bone endothelium help recruit circulating cells, particularly haematopoietic cells to the bone marrow and coordinate with metastatic cells to target them to skeletal regions (Brandi and CollinOsdoby, 2006). Thus, any alteration in the vascular supply to the bone tissue can lead to skeletal pathologies such as osteonecrosis (Childs, 2005); osteomylitis (Lazzerini et al., 2004); and osteoporosis (Burkhardt et al., 1987; Alagiakrishnan et al., 2003). A number of factors have been found to have a prominent effect on the pathology of the vasculature and skeleton, including Osteoprotegerin (OPG), which inhibits Receptor Activator of $\mathrm{NF}^{\sim} \mathrm{B}$ Ligand (RANKL) induced osteoclastogenic bone resorption (Bucay et al., 1998). Transgenic mice over expressing OPG display a marked increase in bone density (osteopetrosis) with very few active osteoclasts (Simonet et al., 1997). Additionally, mice deficient in OPG exhibit an osteoporotic phenotype characterised by a decrease in bone density, severe trabecular and cortical porosity and high incidence of fractures. However, OPG-deficient mice also exhibit medial calcification of the aorta and renal arteries, indicating a role for OPG in the association between osteoporosis and vascular calcification (Bucay et al., 1998).

\section{The role of angiogenesis in bone development}

Intramembranous and endochondral ossification

Development and formation of the skeleton (ossification) occurs by two distinct processes: intramembraneous and endochondral ossification. Both intramembraneous and endochondral bone ossification occur in close proximity to vascular ingrowth. Intramembraneous ossification is characterised by invasion of capillaries into the mesenchymal zone, and the emergence and differentiation of mesenchymal cells into mature osteoblasts. These osteoblasts constitutively deposit bone matrix leading to the formation of bone spicules. These spicules grow and develop eventually fusing with other spicules to form trabeculae. As the trabeculae increase in size and number they become interconnected forming woven bone (a disorganized weak structure with a high proportion of osteocytes), which eventually is replaced by more organised, stronger, lamellar bone. This type of ossification occurs during embryonic development and is involved in the development of flat bones in the cranium, various facial bones, parts of the mandible and clavicle and the addition of new bone to the shafts of most other bones. In contrast, bones of load bearing joints form by endochondral formation (Marks and Hermey, 1996).

Endochondral ossification utilises the functional properties of cartilage and bone to provide a mechanism for the formation and growth of the skeleton. The coupling of chondrogenesis and osteogenesis to determine the rate of bone ossification is dependent on the level of vascularisation of the growth plate (Gerber and Ferrara, 2000). Indeed, vascular endothelial growth (VEGF) factor isoforms are essential in coordinating metaphyseal and epiphyseal vascularization, cartilage formation, and ossification during endochondral bone development (Maes et al., 2004).

The vascularisation of cartilage regions in long bones occurs at different stages of development. Initially, in early embryonic development, blood vessels that originate from the perichondrium invaginate into the cartilage structures. Secondly, during elevated postnatal growth, capillaries invade the growth plate of long bones and thirdly, in adulthood, angiogenesis can be periodically switched on during bone remodelling in response to bone trauma or pathophysiological conditions such as rheumatoid arthritis (RA) and osteoarthritis (OA) (Gerber and Ferrara, 2000).

\section{The role of angiogenic factors in early bone development}

In the embryonic limb bud, during foetal development, mesenchymal precursors differentiate into cartilage cells through a process known as mesenchymal precartilage condensation (Gerber and Ferrara, 2000). This process allows the mesenchymal precursor cells to expand resulting in the development of a structure similar to that of long bones. Vascular invasion of the cartilage template structure is concomitant with hypertrophic differentiation of chondrocytes in the diaphysis of the bone. Subsequently, these chondrocytes in the central region of the cartilage undergo hypertrophy and synthesize an extracellular matrix 


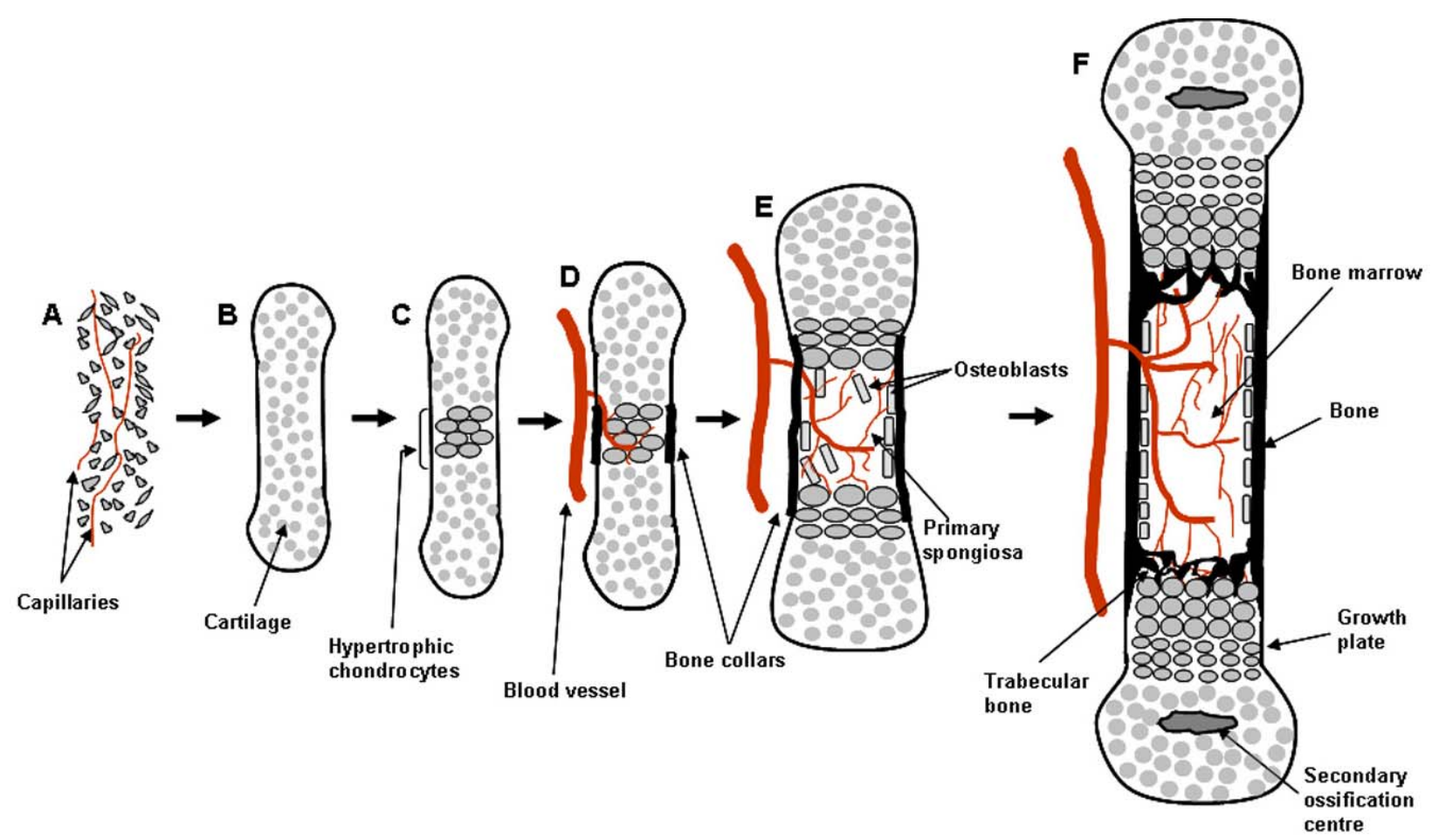

Figure 1. A schematic diagram of endochondral bone formation. (A) Mesenchymal cells condense and (B) differentiate into chondrocytes forming an avascular cartilage model of the future bone. $(C)$ At the centre of condensation the chondrocytes cease proliferating and become hypertrophic. (D) Perichondral cells adjacent to the hypertrophic chondrocytes differentiate into osteoblasts forming a bone collar. The hypertrophic cartilage regulates the formation of mineralised matrix; the release of angiogenic factors to attract blood vessels and undergoes apoptosis. (E) The coordination of osteoblasts and vascular invasion form the primary spongiosa. The chondrocytes continue to proliferate with concomitant vascularisation resulting in a coordinated process that lengthens the bone. Osteoblasts of the bone collar will eventually form cortical bone; while osteoblasts precursors located in the primary spongiosa will eventually form trabecular bone. (F) At the ends of the bone, secondary ossification centres develop through cycles of chondrocyte hypertrophy, vascular invasion and osteoblast activity. Columns of proliferating chondrocytes form in the growth plate beneath the secondary ossification centre. Finally, expansion of stromal cells and hematopoietic marrow starts to take place in the marrow space (Adapted from Kronenberg, 2003 and Horton, 1990).

that is different in composition from that of the proliferating cartilage of which Collagen Type $\mathrm{X}$ is a unique component (Iyama et al., 1991). Vascular Endothelial Growth Factor A(VEGF A), a 34-46kD homodimeric glycoprotein, which acts through its high affinity receptor VEGF R2 (Flk-1/ KDR), and a critical signalling molecule involved in early blood vessel development is secreted by the hypertrophic chondrocytes inducing sprouting angiogenesis from the perichondrium leading to the recruitment of osteoblasts, osteoclasts and haematopoietic cells. These sequences of events lead to the development of the primary ossification centres. The hypertrophic matrix within these centres then degrades, and the recruited osteoblasts replace the degraded cartilage with trabecular bone and a bone marrow is thus formed (Hall et al., 2006; Gerber and Ferrara, 2000; CollinOsdoby, 1994). Simultaneously, osteoblasts in the perichondrium form a collar of compact bone around the middle portion (diaphysis) of the cartilage; as a result, the primary ossification centre ends up within a tube of bone. At both ends (epiphyses) of the cartilage, secondary ossification centres are formed, creating a cartilaginous plate (growth plate) between epiphysis and diaphysis (Figure 1).
A synchronized sequence within the growth plate of chondrocyte proliferation, hypertrophy, apoptosis and vascular invasion results in longitudinal growth of long bones (Hunziker, 1994). The balance of cartilage formation and vascular invasion is critical for the elongation of long bones. Disruption of this coordinated balance and the uncoupling of the tightly regulated vascular invasion will lead to growth plate thickening and a reduction in bone formation (Yabsley and Harris, 1965). The coordination of these processes leads to the growth of the epiphysis and radial growth of the diaphysis. The immature and proliferating chondrocytes in early osteogenesis express and secrete angiogenic inhibitors (Moses et al., 1990; Hayami et al., 2003) and ECM rich in type II collagen and aggrecan (Orth, 1999). These cells differentiate into hypertrophic chondrocytes and control ossification by an expression cascade of angiogenic factors VEGF, acidic Fibroblast Growth Factor (aFGF), basic Fibroblast Growth Factor (bFGF) and, Type X collagen, MMP13 and alkaline phosphatase (Baron et al., 1994; Nagai and Aoki, 2002; Gerber et al., 1999; Horner et al., 1999; Carlevaro et al., 2000; Maes et al., 2002; Alini et al., 1994; Ivkovic et al., 2003; Väänänen, 1980). A combination of hypertrophic 
chondrocytes and migrating cells from the newly formed marrow degrade the extracellular matrix by secreting matrix metalloproteinases $2,9, \& 13$. This degradation of the matrix leads to the loss of the transverse septum within the chondro-osseous junction. This septum is a barrier between the hypertrophic chondrocytes undergoing apoptosis and the blood vessel invading region (Hall et al., 2006).

Hypertrophic chondrocytes express and synthesize a number of VEGF isoforms, VEGF-A, VEGF-B, VEGF$\mathrm{C}, \mathrm{VEGF}-\mathrm{D}$ and also express neuropilin-1, VEGF receptor2 and VEGF receptor-3 (Bluteau et al., 2007). This autocrine/paracrine system will further encourage inwards penetration of the vascular endothelium (Peterson et al., 2002). The apoptotic chondrocytes lay down a mineralised cartilage scaffold, which becomes the template for bone modelling by invading osteoblasts and osteoclasts. The osteoblasts differentiate on these scaffold templates in between columns of hypertrophic chondrocytes forming primary trabeculae bone. Infiltration of the endothelium into the empty lacunae of terminal hypertrophic chondrocytes enhances the functional differentiation of other VEGFR expressing cells particularly osteoblasts and osteoclasts (Midy and Plouët, 1994; Deckers et al., 2000; Engsig et al., 2000; Maes et al., 2002).

In vivo studies have shown that inhibition of VEGF signalling leads to i) a dose-dependent increase in the femoro-tibial epiphyseal growth plate zone of hypertrophy (Wedge et al., 2002), ii) reduced angiogenesis in growth plates, iii) loss of metaphyseal blood vessels and, iv) a reduction in trabecular bone formation (Haigh et al., 2000; Gerber et al., 1999) and a stimulation in trabecular resorption (Yao et al., 2004). VEGF has multifarious activities in bone development, regulating the survival and activity of endothelial, chondrogenic and osteogenic cells, and promoting vascularisation during endochondral bone formation (Coultas et al., 2005). In the developing long bones VEGF is expressed before any blood vessels are detected and this expression is linked to the bone formation process (Carano and Filvaroff, 2003; Zelzer et al., 2002). Indeed, the Hypoxia Inducible Factor- $\alpha$ (HIF- $\alpha$ ) pathway has been demonstrated to be critical in coupling angiogenesis and osteogenesis during long bone formation. This increase in bone formation is due to enhanced angiogenic activity, which is mediated by elevated levels of VEGF in HIF- $\alpha$ overexpressing osteoblasts (Wang et al., 2007).

Although VEGFs' main effects are on endothelial cells, they also bind to VEGF receptors expressed on monocytes, neurons, chondrocytes and osteoblasts (Ferrara et al., 2003; Storkebaum and Carmeliet, 2004; Bluteau et al., 2007). Apart from VEGFs' potent angiogenic effects they can induce haematopoietic stem cell recruitment from the bone marrow, monocyte chemoattraction, neuronal protection as well as bone formation (Ferrara et al., 2003; Storkebaum and Carmeliet, 2004; Geiger et al., 2005; Peng et al., 2005). VEGF and matrix metalloproteinase-9 (MMP-9) are critical for early bone development (Engsig et al., 2000). Mice completely lacking in MMP-9 (gelatinase B) have delayed endochondral ossification and an abnormally large hypertrophic cartilage zone in growth plates (Vu et al.,
1998) indicating that MMP-9 and possibly other metalloproteinases play a critical role in normal apoptosis of hypertrophic chondrocytes. VEGF binds to the extracellular matrix and is made available by MMP-9 (Bergers et al., 2000). It has been hypothesized that MMP9 makes VEGF bioavailable from hypertrophic cartilage, functionalizing as a chemoattractant to promote vascular invasion.

The molecular pathways regulating VEGF expression in hypertrophic cartilage are not clear, however, it is been determined that in Runx2 (transcription factor associated with osteoblast differentiation) homozygous null mice, no blood vessel ingrowth into the cartilage occurs, not even in regions where there is notable chondrocyte hypertrophy (Otto et al., 1997). Hence, expression of Runx2 may regulate VEGF expression and angiogenesis at the junction between growth plates and the trabeculae in long bones by upregulating VEGF or down regulating anti-angiogenic factors.

\section{Vascularisation in bone}

Vascularisation of the cartilaginous region in the primary ossification centre during embryogenesis differs from the vascular invasion of the growth plate region during postnatal periods of rapid skeletal growth. In embryos, endothelial cells develop into immature vascular networks that enter the bone structure via cartilage canals already established in the expanding cortical bone (Burkus et al., 1993). Whereas, during postnatal bone growth, canal formation for blood vessels develops in unison with vessel formation at the growth plate region (Gerber and Ferrara, 2000).

The main vessel supply networks to long bones are the nutrient artery, the metaphyseal, epiphyseal and periosteal arterial networks (Clemens, 1996). The bone vasculature comprises of an arteriole, which divides into a complex anastomising network of capillaries (Visco et al., 1989) and sinusoidal vessels. The sinusoids in the bone marrow are characterized by a highly permeable thin wall consisting of a single layer of endothelial cells, which are supported in part by a vascular membrane, pericytes, and reticular cells (Nikolova et al., 2006a). Sinusoids surrounded by reticular cells secrete high amounts of a chemokine, CXCL12 (SDF-1), which is required for the maintenance of human stem cells (Sugiyama et al., 2006). These capillaries then double back and connect to a single venule, which follows the arteriole route returning to the perichondral plexus (Hayashi, 1992). These vascular networks supply nutrients required by the chondrocytes, and mesenchymal cells for chondrogenesis and osteogenesis in order to maintain a functional secondary ossification centre (Ytrehus et al., 2004; Marotti and Zallone, 1980; Kugler et al., 1979). Therefore, the development of these vessel networks is integral to the homeostasis of bone.

\section{Interaction of endothelium and bone}

The microvascular endothelium is an essential part of skeletal tissue, where the intercellular signalling between endothelium and bone cells plays a critical role in the homeostasis of bone integrity. Human Umbilical Vein 
Endothelial Cells (HUVEC) conditioned medium enhances the proliferation of Human Bone Marrow Stromal cells (HBMSC) and when HBMSC and HUVEC are co-cultured in vitro, the expression and activity of the early osteoblastic marker Alkaline Phosphatase (AP) is elevated, but only in direct contact with each of the cell types (Villars et al., 2000). Both HBMSC and the endothelial network express connexion $43(\mathrm{Cx} 43)$ a specific gap junction protein. These two cell types can therefore communicate via a gap junctional channel constituted at least by $\mathrm{Cx} 43$ (Villars et al., 2002). Conversely, Meury et al., 2006 showed HUVEC to affect dexamethasone-induced HBMSC differentiation into osteoblasts, by inhibiting the expression of Osterix (OSX). Thus, the rate of differentiation of bone marrow stromal cells (HBMSC) to osteoblasts maybe controlled by endothelial cells, by initiating the recruitment of osteoprogenitor cells at sites of bone remodelling and maintaining them in a pre-osteoblastic stage, hence avoiding mineral deposition within the vessel. Once these osteoblast precursors have migrated from the vessels towards a remodelling/bone forming site, the onset of rapid differentiation should occur into mature functional osteoblasts intent on laying down new osteoid.

The intercellular signalling pathways of endothelial cells have also been implicated in the functions of the osteoclastic lineage. For the recruitment of osteoclasts to areas of bone resorption, osteoclast precursors need to adhere and migrate through the endothelium in a tightly regulated mechanism similar to that of the systematic process of transendothelial migration of leukocytes and monocytes (Imhof and Dunon, 1997). It has been hypothesised that the endothelium may direct osteoclast precursor to specific areas of bone to help tightly control the resorptive process (Parfitt, 2000). Therefore, alterations in the micro-vascular supply network will ultimately affect the tightly regulated resorption sequence resulting in decreases in bone formation, regeneration and repair as well as altered osteointegration of orthopaedic and dental implants (Glowacki, 1998; Burkhardt et al., 1987).

Bone endothelial cells display their own distinctive characteristics, with a capacity to respond to bone regulators such as cytokines, estrogen and PTH (Streeten et al., 1989; Streeten and Brandi, 1990; Brandi et al., 1993). In addition, bone endothelial cells secrete high levels of hormone B-type Natriuretic peptide (Bordenave et al., 2002) and express the chemoattractant, stromal cellderived factor-1 (SDF-1) (Imai et al., 1999). Differences have also been noted in the sulphation patterns of heparansulphate derived from human bone endothelial cells and HUVECs (Netelenbos et al., 2001), the adhesion of hematopoietic progenitor cells to human bone marrow or HUVEC, (Rood et al., 1999) and the selective secretion of chemoattractants for hematopoietic progenitor cells by bone marrow endothelial cells (Imai et al., 1999). These specific signals lead to hematopoietic progenitor cell homing maintaining a constant supply of precursor cells into bone (Brandi and Collin-Osdoby, 2006).

Furthermore, Macrophage Colony Stimulating Factor (MCSF), Receptor activating NF- $\mathrm{BB}$ ligand (RANKL) Osteoprotegerin (OPG) are all expressed by endothelial cells, particularly OPG which co-localises with P-selectin and von Willebrand factor within the Weibel-Palade bodies of HUVEC (Yoshida et al., 1990; Collin-Osdoby et al., 2001; Zannettino et al., 2005). Similarly, factors involved in bone remodelling and repair can alter osteoblastic activity. These include Bone Morphogenic Proteins (BMP), fibroblast growth factors, prostaglandins, VEGF, platelet derived growth factors, PTH, insulin growth factor-1, reactive oxygen and nitrogen species (Carano and Filvaroff, 2003; Kanczler et al., 2003, Zheng et al., 2006). Indirectly, osteogenic factors such as BMP-2 can stimulate osteoblast VEGF and hence modulate vascularisation (Deckers et al., 2000). Additionally, BMP-2 has the capability to inhibit hypoxia-induced cell apoptosis and promote vascularisation and possibly tumour angiogeneis (Raida et al., 2006). Whilst, transient changes in oxygen tension and oscillatory shear stress can induce BMP-2 growth factor expression in endothelial cells (Salim et al., 2004, Sorescu et al., 2003).

Hypoxia and VEGF lead to an upregulation of BMP-2 in microvascular endothelial cells (Bouletreau et al., 2002) demonstrating the intricate signalling pathways affecting the interactive relationship of endothelial cells and cells of the osteoblastic lineage. These stress/strain and oxygen sensitive pathways may play a role in the response of endothelial cells at a fracture site and hence be at the forefront of the repairing mechanistic cascade producing numerous factors such as BMPs that can act reciprocally on the osteoblast lineage and affect the rate of fracture repair

\section{Angiogenesis and bone fracture repair}

Bone has the unique capacity to regenerate without the development of a fibrous scar, which is symptomatic of soft tissue healing of wounds. This is achieved through the complex interdependent stages of the healing process, which mimics the tightly regulated development of the skeleton. Hence, if fibrous scars were to develop in bone it would ultimately compromise the mechanical properties of the skeleton. Following trauma with damage to the musculoskeletal system, disruption of the vasculature leads to acute necrosis and hypoxia of the surrounding tissue (Glowacki, 1998). This disruption of the circulation leads to the activation of thrombotic factors in a coagulation cascade leading to the formation of a haematoma. The inflammatory response and tissue breakdown activate factors such as cytokines and growth factors that recruit osteoprogenitor and mesenchymal cells to the fracture site. The stimulation of the endosteal circulation in the fractured bone (Rhinelander, 1974) allows mesenchymal cells associated with growing capillaries to invade the wound region from the endosteum and bone marrow (Uchida et al., 2003). At the edge of the bone fractures, the transiently formed granulation tissue is replaced by fibrocartilage. Concomitantly, the periosteum directly undergoes intramembranous bone formation leading the formation of an external callus (Carano and Filvaroff, 2003); while internally, the tissue is being mineralised to form woven bone. After stabilisation of the bone tissue and vasculature in the bone fracture, the cell mediated remodelling cascade is activated where osteoclastic removal of necrotic bone 
tissue is accompanied by angiogenesis, which in turn is followed by the replacement of the large fracture callus by lamellar bone. The callus size is reduced and the normal vascular supply is restored.

A plethora of mediators associated with foetal and postnatal bone development play a prominent role in the cascade response in bone fracture repair. These include BMP-2 \& 4 (Barnes et al., 1999; Deckers et al., 2002; Kloen et al., 2003), VEGF (Midy and Plouet, 1994; Deckers et al., 2000; Street et al., 2002; Ferrara et al., 2003), bFGF (Rodan et al., 1989; Montesano et al., 1986), TGF- $\beta$ (Rosier et al., 1998; Bostrom and Asnis, 1998; Erlebacher et al., 1998), PDGF (Mandrachia et al., 2001; Risau et al., 1992). VEGF expression is detected on chondroblasts, chondrocytes (Pufe et al., 2001), osteoprogenitor cells and osteoblasts in the fracture callus (Tatsuyama et al., 2000) where it is highly expressed in angioblasts, osteoprogenitor and osteoblast cells during the first seven days of healing but decreases after eleven days (Uchida et al., 2003). Additionally, osteoclasts release heparinase that induces the release of the active form of VEGF from heparin, activating not only angiogenesis but also osteoclast recruitment, differentiation and activity leading to the remodelling of the fracture callus during endochondral ossification (Saijo et al., 2003; Niida et al., 1999; Engsig et al., 2000; Nakagawa et al., 2000). In the bone remodelling sequence Niida et al., (1999) showed VEGF can act with sRANKL to promote osteoclastogenesis and that a single injection of recombinant human VEGF can similarly induce osteoclast recruitment in op/op mice, suggesting that VEGF can act as a substitute for M-CSF in osteoclastogenesis. Street and colleagues (Street et al., 2000; Street et al., 2002; Ryan et al., 1999; Gerber et al., 1999) have demonstrated that the inhibition of VEGF in fractured mouse femurs results in a decrease in blood vessel invasion with a reduction in osteoclastic bone remodelling, impaired callus mineralization and reduced trabecular bone healing.

Fractures in some cases fail to repair or unite resulting in fibrous filled pseudoarthrosis. A number of contributing factors can lead to non-union or delayed union of bone fractures, such as anti-inflammatory drugs, steroids, Vitamin C, D and calcium deficiencies (Glowacki, 1998). The absence of a functional vascular network is also a fundamental factor in the lack of bone healing in non-union fractures. With this in mind researchers have shown that angiogenic factors released from biomimetic scaffolds can enhance bone regeneration (Murphy et al., 2004) and, furthermore, that combination strategies that release both angiogenic and osteogenic factors can further enhance the regenerative capacity of bone (Geiger et al., 2005; Peng et al., 2005).

The critical sequential timing of osteoclast differentiation and activation, angiogenesis, recruitment of osteoprogenitor cells and the release of growth factors such as BMP-2 in osteogenesis and fracture repair maybe enhanced by the synchronized endogenous production of angiogenic and osteogenic mediators (Glowacki, 1998). Studies in the rat femoral drill-hole injury have shown differential expression of VEGF splicing isoforms along with its receptors indicating an important role in the bone healing process (Uchida et al., 2003). Also, Sojo et al. (2005) demonstrated that angiogenesis occurs predominantly before the onset of osteogenesis in bone lengthening in an osteodistraction model.

Another angiogenic inducing growth factor, FGF-2, (Coffin et al., 1995; Montero et al., 2000) has the capability to accelerate fracture repair when added exogenously to the early healing stage of a bone. (Kawaguchi et al., 1994; Nakamura et al., 1997; Inui et al., 1998; Kawaguchi et al., 2001, Chen et al., 2004). Although the mechanism has not been fully elucidated, it has the ability to stimulate angiogenesis (Montesano et al., 1986; Hayek et al., 1987; Collin-Osdoby et al., 2002) and, the proliferation and differentiation of osteoblasts (Globus et al., 1988; Nakamura et al., 1995; Walsh et al., 2000; Pun et al., 2001) to possibly aid the repair of bone fractures.

Disruption of the normal bone vasculature can result in skeletal problems such as osteopetrosis (Aharinejad et al., 1995; Aharinejad et al., 1999), metastatic bone disease (Taichman et al., 2002) and inflammatory bone loss in rheumatoid arthritis and periodontal disease (Findlay and Haynes, 2005; Walsh and Mapp, 1998; Schwartz et al., 2000). Thus, we are now beginning to understand the intimate relationship between the vasculature and bone, and the important role played in maintaining bone homeostasis, offering the possibility of novel new approaches to solving the problems of fracture healing, particularly in delayed and non-union pathologies.

\section{Skeletal tissue engineering, the clinical need for new bone}

With an increasing aging population the numbers of hip fractures worldwide are projected to increase from 1.7 million in 1990 to 6.3 million in 2050 (Johnell, 1997). Indeed, in the United States alone, 6 million fractures occur annually of which $5-10 \%$ will require further treatment for the loss of bone, failed fracture fixation, infection, and the inhibition of a blood supply (Praemer et al., 1992; Cheung, 2005).

Graft material such as autologus, allogeneic bone and metallic implants are currently used to address these challenging clinical bone loss pathologies. Unfortunately, these techniques face serious limitations due the possible risk of infection and rejection, limited stock supplies and cost (Oreffo and Triffitt, 1999; Bauer and Muschler, 2000). Hence, the ability to generate new bone graft substitutes for skeletal use is a major clinical need.

A variety of porous scaffold polymers (naturally derived or synthetic matrices) have shown promising potential for bone tissue engineering applications. Natural polymers such as collagen are of a major interest because they are biodegradable and biocompatable, allowing cells to adhere, proliferate and differentiate without the problems of inflammatory reactions and cytotoxicity which are often associated with synthetic polymers. (Lu et al., 2004; Lubiatowski et al., 2006; Domaschke et al., 2006). However, natural polymers are structurally complex compared to synthetic polymers therefore, technical manipulation is complicated and more elaborate causing 
variation in the processing of consistent scaffold matrices. Additionally, these polymers lack the mechanical properties, which are required to withstand the forces, which for example exist in the bone environment. Synthetic polymer matrices, polylactic acid (PLA) polyglycolic acid (PGA and poly(lactic-co-glycolic) (PLGA) acid polyorthoesters, polycaprolactones, polycarbonates, and polyfumerates which are free of potential contamination, can be readily engineered (Agrawal and Ray, 2001; Sachlos and Czernuszka, 2003). These have proven versatility and can be developed as $3 \mathrm{D}$ porous monolithic structures that can be custom-designed to fit the anatomical bone defect in an individual patient (Popov et al., 2004; Antonov et al., 2005). However, one of the major problems with these types of scaffolds is the lack of osteoconductivity compared to the current gold standard of allograft. Researchers have tried to overcome these problems by combining ceramics such as hydroxyapaptite (HA) and calcium phosphate with the synthetic polymers PLA or PLGA (Popov et al., 2004; Khan et al., 2004; Wei and Ma, 2004; Ruhe et al., 2005a). With the fabrication of the osteoconductive/osteoinductive scaffolds, novel approaches are being developed to enhance the engineered scaffolds by the addition of growth factors and osteoprogenitor cells to promote bone growth.

Bone marrow derived human mesenchymal or skeletal stem cells (SSC) when seeded on to nanofibrous poly (ecaprolactone) scaffolds can be differentiated into an osteogenic lineage (Li et al., 2005). Ruhe et al. (2005b) showed bioactive factors to be incorporated into (PLGA/ Ca-P cement) composites and could be slowly released. Furthermore, the combination of osteogenic growth factor release (BMP-2) from polymer scaffolds such as PLA and the addition of preosteogenic cells have further increased the possibility of engineering bone (Rose et al., 2004; Yang et al., 2004; Montjovent et al., 2005; Montjovent et al., 2007; Georgiou et al., 2007), whilst Jansen et al. (2005) demonstrated orthotopic bone formation in a rabbit cranial defect model stimulated in rhTGF $\beta 1$ and rhBMP-2 CaP cement and Titanium-fibre mesh scaffolds.

However, unlike organ transplants where there is a preexisting vascular supply, synthetic bone constructs are devoid of a pre-existing vasculature. Researchers are now trying to address this problem of whether it is a prevascularised scaffold developed in vitro or the release of angiogenic factors from scaffolds that promote angiogenesis in situ that will optimally enhance bone morphogenesis in situ. Development of these bone scaffolds requires an internal interconnecting microarchitecture sufficiently porous to promote cellingrowth and significantly strong enough to withstand the exerted forces on bone (Logeart-Avramoglou et al., 2005). Enhanced migration of endothelial cells into the matrix to develop vascular beds will be critical to the survival of these implanted bone constructs. At first, the implants will depend on surrounding diffusive nutrient supply and waste removal processes until the engineered tissue becomes vascularised. This is critical, as bone defects are often large and nutrient diffusion is optimally effective within 150$200 \mu \mathrm{m}$ from the blood supply source (Sutherland et al., 1986; Colton, 1995). The efficacy of cells such as osteoprogenitors seeded onto these scaffolds and transplanted will depend upon local vasculature and the speed at which a fully functional vascular supply can be developed. Temporary exposure of SSCs to hypoxia, results in the down-regulation of $\mathrm{Cbfa}-1 / \mathrm{Runx} 2$, osteocalcin and type I collagen, and the up-regulation of osteopontin and VEGF (Potier et al., 2007a). Prolonged concomitant hypoxic regions and lack of nutrients will ultimately lead to significant cell death (Potier et al., 2007b). Vogelin et al., (2005) demonstrated the importance of the vasculature in bone repair. Their engineered scaffold (polylactic acid-Hyaluronan acid matrix and BMP-2) provided good bone formation in a critical rat femur defect. However, when they added a vascularised periosteal flap to the scaffold/defect there was a significant increase in bone formation within the boundaries of the defect and a prevention of any heterotopic ossification.

Recent studies show that primitive vascular networks derived from endothelial cells that were implanted in vivo remain immature and do not survive. However, the addition of the anti-apoptotic $\mathrm{Bcl} 2$ gene into endothelial cells can increase survival and formation of blood-perfused blood vessels that differentiate and develop into arteries, veins and capillaries (Schechner et al., 2000). It is not known how long these vessels continue to function or the oncogenic potential these genetic manipulations may cause. Additionally, retroviral-mediated transduction of hTERT in human dermal microvascular endothelial cells (HDMEC) when implanted subcutaneously results in the development of microvascular structures (Yang et al., 2001).

Co-implantation of perivascular cell precursors and endothelial cells in engineered constructs leads to longlasting, stable microvessels in vivo; which are fully functional for more than one year (Koike et al., 2004). The seeding of relevant cells has led to the successful bioengineering of muscle and blood vessels. In 2005, Levenberg et al. demonstrated using a tri-culture system consisting of endothelial cells, myoblasts and embryonic fibroblasts for tissue engineered muscle that the development of vascular networks was of a higher density compared to a co-culture system of endothelial cells and myoblasts. An increase in VEGF expression was identified as the factor, which mediated these elevated levels in vessel density.

Typically, therapeutic strategies for the regeneration of tissue have relied on the bolus delivery of single growth factors. Although this has been successful in animal models of therapeutic angiogenesis (Takeshiti et al., 1994) this success has not, to date, been able to be translated to the clinic (Simons et al., 2000). Recent developments in bioengineering scaffold design have led to growth factors to be incorporated onto or entrapped within the scaffolds. (Murphy et al., 2000; Murphy et al., 2004; Yang et al., 2004; Huang et al., 2005a; Huang et al., 2005b; Jansen et al., 2005; Kaigler et al., 2006a; Leach et al., 2006; Oest et al., 2007; Jeon et al., 2007; Kanczler et al., 2007; Hou et al., 2007; Wei et al., 2007; Tai et al., 2007; Chang et al., 2007). As these scaffolds are biodegradable, bioactive factors can be released locally over a period of time. Kaigler et al. (2006a) demonstrated VEGF scaffolds could enhance neovascularization and bone regeneration in irradiated 

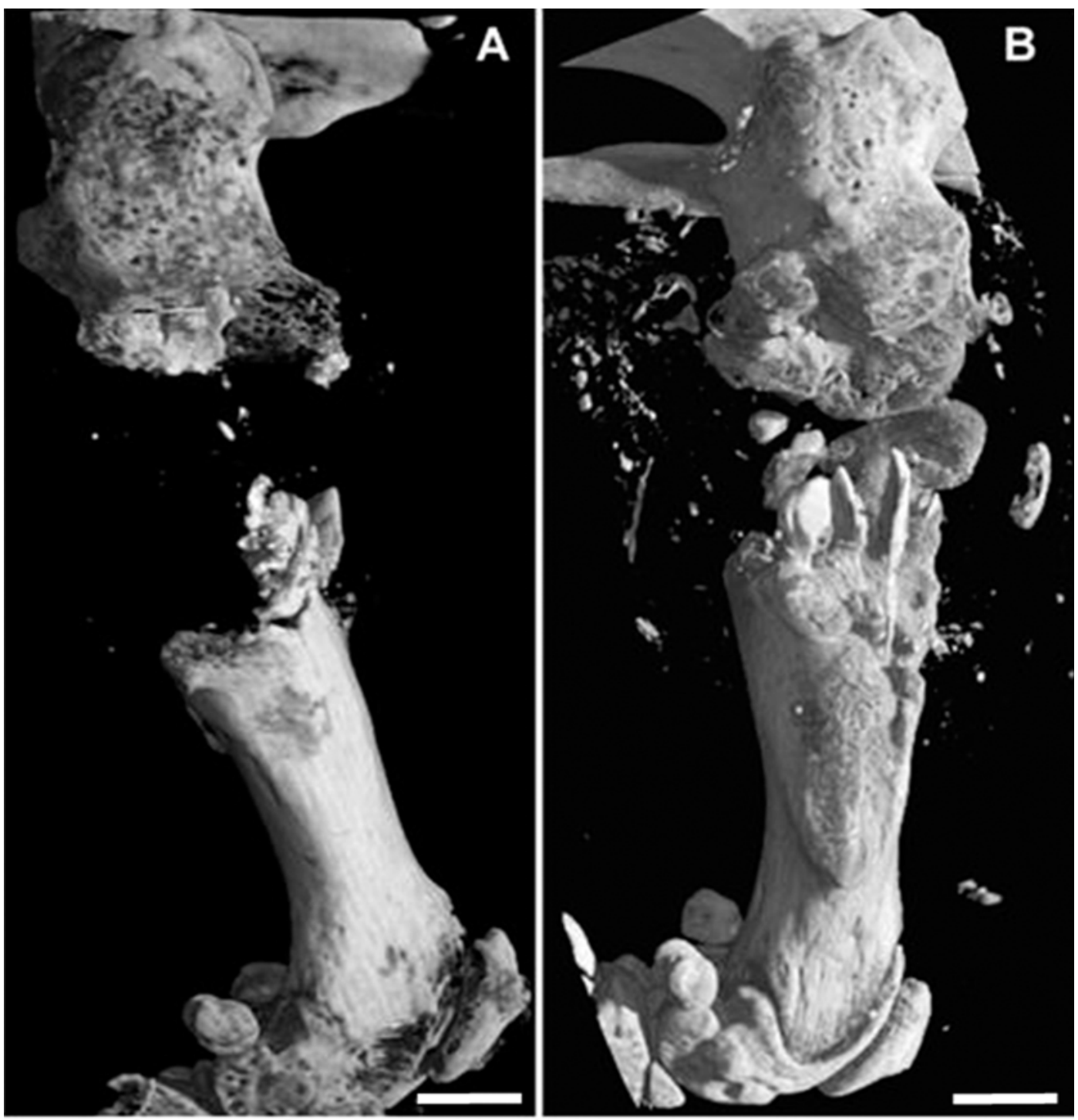

Figure 2. Micro-CT images of murine segmental femur $(5 \mathrm{~mm})$ defects at 4 weeks post operation. (A) Represents a control segmental femur defect, (B) represents encapsulated VEGF and BMP-2 in a composite alginate / Poly (DL) lactic acid scaffold with seeded HBMSC implanted within the femur defect. Bar $=1.5 \mathrm{~mm}$.

osseous defects. Whereas, load-bearing BMP-2 scaffolds can maintain bone length and enhance regeneration of bone in a critical sized defect (Chu et al., 2007). BMP-2 and TGF- $\beta 3$, combined with RGD-alginate hydrogel codelivered to critical sized femoral defects $(8 \mathrm{~mm})$ within polymer scaffolds showed an increase in bone formation (Oest et al., 2007).

Recent studies have shown that the combination of angiogenic and osteogenic factors can stimulate bone healing and regeneration (Geiger et al., 2005; Peng et al., 2005). Therefore, the ability to deliver a combined delivery system of growth factors at different rate kinetics locally from biodegradable scaffolds could enhance the reparative mechanism of critical sized bone defects; thus, mimicking the in vivo bone repair conditions. Richardson et al. (2001) developed a polymeric system for tissue specific controlled release delivery from a structural polymer scaffold of two or more growth factors, PDGF-BB and VEGF-165. This combination of PDGF-BB and VEGF-165 initiated formation and maturation of a significant number of blood vessels. A multiple release of growth factors such as VEGF and BMP-2 may in fact be able to mimic the conditions in bone fracture repair. Hence, a scaffold able to release an active angiogenic factor will promote early vascularisation and attract osteogenic precursor cells. Dual release growth factor (VEGF \& BMP-2) fabricated scaffolds developed by Shakesheff, Howdle and colleagues at the University of Nottingham have shown the efficacy of use of these types of scaffolds in a critical sized murine femur bone defect model. Figure 2 demonstrates the significant effect of the release of angiogenic (VEGF) and osteogenic (BMP2) factors from a biodegradable scaffold seeded with human bone marrow stromal cells on the regeneration of bone in a critical sized mouse femur defect. Hence, the combined effect of human bone marrow stromal or enriched mesenchymal stem cells seeded onto these new generation of growth factor encapsulated scaffolds could result in the co-development of vessels and bone in situ, providing a reciprocal approach to the fast development of vascularised engineered bone constructs. Conversely, transplantation of endothelial cells can enhance bone marrow stromal-cell-mediated bone regeneration in an 
osseous defect (Kaigler et al., 2006b). PLGA scaffolds containing a combination of plasmids encoding DNA for BMP-4, VEGF and human bone marrow stromal cells promoted greater bone formation when implanted into the subcutaneous tissue of SCID mice relative to a single factor or a combination of two factors (Huang et al., 2005a). Previously, Yang and colleagues demonstrated that BMP2 growth factor can be incorporated into biodegradable Poly (DL-lactic acid) scaffolds by a method of supercritical carbon dioxide $\left(\mathrm{scCO}_{2}\right)$ fluid mixing technology without the loss of activity. These generated scaffolds have the ability to release active BMP-2 and promote osteoprogenitor differentiation and bone formation in vitro and in vivo (Yang et al., 2004). Development of complex biomimetic scaffolds has resulted in the ability kinetically to release VEGF quickly followed by slow release of BMP2 mimicking the sequences these growth factors are released in fracture repair process. The addition of seeded human bone marrow cells or progenitor cells onto these dual release scaffolds will produce some of the key components to enhance the repair of delayed or non-union delayed fractures.

In conclusion, the ability to deliver, over time, a combination of cells and growth factors in a regulated manner from biocompatible scaffolds to sites of tissue regeneration that promote angiogenesis and osteogenesis offers significant therapeutic opportunities for a variety of tissue engineered scaffolds

\section{Conclusion}

Angiogenesis plays a critical role in the systematic growth and repair of bone. With the progression of new research tools osteogenic and angiogenic molecules involved in the signalling pathway cascade in the development of bone are slowly being elucidated. Understanding the paracrine relationship between bone cells and endothelial cells and the signalling molecules therein will undoubtedly unveil key mechanisms involved in bone morphogenesis, and offer insights into the development and of new strategies for the delivery of targeted therapies to bone related diseases particularly individuals at risk for delayed repair or non-unions.

Increasing our understanding will ultimately help in devising new approaches in vascularised engineered tissue constructs. Optimising drug delivery to angiogenic and antiangiogenic molecules that effect vessel growth in the bone environment may prove beneficial for targeting either bone destruction or inducing bone growth. Slow release growth factor/scaffold formulations, gene therapy and stem cells are all currently being used to enhance bone fracture repair and regeneration. Groups have now developed intelligent scaffolds that can now release growth factors with appropriate release kinetics to induce angiogenesis and bone morphogenesis. These new generations of scaffolds allow for the angiogenesis to be switched on and halted therefore stimulating the right amount of angiogenesis to repair bone and avoiding a chronic inflammatory reaction. The addition of stem cell based therapies to these scaffold designs will, ultimately, provide vascular and osteogenic precursors that will enhance the development of the tissue- engineered construct.

A better understanding of the interaction of bone vascular biology and osteogenesis will enhance our knowledge and help in the design of novel rational strategies for the treatment of bone diseases. Harnessing the cellular and molecular interactions between endothelial populations and bone cell populations has already enhanced and augmented the process of skeletal tissue engineering. The development of bioengineered bone remains an exciting promising alternative approach to skeletal repair, with the potential, to impact on daily clinical practice.

\section{Acknowledgements}

We would like to thank the members of the Bone \& Joint Research Group for many helpful discussions in preparing this manuscript, and to Professor Kevin Shakesheff, Professor Steve Howdle (University of Nottingham) and Professor Julian Chaudhuri (University of Bath) for extensive collaborations. This work was supported by grants from the Biotechnology and Biological Sciences Research Council (BBSRC) and Engineering and Physical Sciences Research Council (EPSRC).

\section{References}

Agrawal CM, Ray RB (2001) Biodegradable polymeric scaffolds for musculoskeletal tissue engineering. J Biomed Mater Res 55: 141-150.

Aharinejad S, Marks SC Jr, Bock P, Mason-Savas A, MacKay CA, Larson EK, Jackson ME, Luftensteiner M, Wiesbauer E (1995) CSF-1 treatment promotes angiogenesis in the metaphysis of osteopetrotic (toothless, tl) rats. Bone 16: 315-324.

Aharinejad S, Grossschmidt K, Franz P, Streicher J, Nourani F, MacKay CA, Firbas W, Plenk H Jr, Marks SC Jr (1999) Auditory ossicle abnormalities and hearing loss in the toothless (osteopetrotic) mutation in the rat and their improvement after treatment with colony-stimulating factor-1. J Bone Miner Res 14: 415-423.

Alagiakrishnan K, Juby A, Hanley D, Tymchak W, Sclater A (2003) Role of vascular factors in osteoporosis. J Gerontol A Biol Sci Med Sci 58: 362-366.

Alini M, Carey D, Hirata S, Grynpas MD, Pidoux I, Poole AR (1994) Cellular and matrix changes before and at the time of calcification in the growth plate studied in vitro: arrest of type X collagen synthesis and net loss of collagen when calcification is initiated. J Bone Miner Res 9: 1077-1087.

Antonov EN, Bagratashvili VN, Whitaker MJ, Barry JJA, Shakesheff KM, Konovalov AN, Popov VK, Howdle SM (2005) Three-dimensional bioactive and biodegradable scaffolds fabricated by surface-selective laser sintering. Advanced Materials 17: 327-330.

Barnes GL, Kostenuik PJ, Gerstenfeld LC, Einhorn TA (1999) Growth factor regulation of fracture repair. J Bone Miner Res 14: 1805-1815. 
Baron J, Klein KO, Yanovski JA, Novosad JA, Bacher JD, Bolander ME, Cutler GB Jr (1994) Induction of growth plate cartilage ossification by basic fibroblast growth factor. Endocrinology 135: 2790-2793.

Bauer TW, Muschler GF (2000) Bone graft materials. An overview of the basic science. Clin Orthop Relat Res 371: 10-27.

Bergers G, Brekken R, McMahon G, Vu TH, Itoh T, Tamaki K, Tanzawa K, Thorpe P, Itohara S, Werb Z, Hanahan D (2000) Matrix metalloproteinase-9 triggers the angiogenic switch during carcinogenesis. Nat Cell Biol 2: 737-44.

Bluteau G, Julien M, Magne D, Mallein-Gerin F, Weiss P, Daculsi G, Guicheux J (2007) VEGF and VEGF receptors are differentially expressed in chondrocytes. Bone 40: 568-576.

Bordenave L, Georges A, Bareille R, Conrad V, Villars F, Amedee J (2002) Human bone marrow endothelial cells: a new identified source of B-type natriuretic peptide. Peptides 23: 935-940.

Bostrom MP, Asnis P (1998) Transforming growth factor beta in fracture repair. Clin Orthop Relat Res 355S: S124-S131.

Bouletreau PJ, Warren SM, Spector JA, Peled ZM, Gerrets RP, Greenwald JA, Longaker MT (2002) Hypoxia and VEGF up-regulate BMP-2 mRNA and protein expression in microvascular endothelial cells: implications for fracture healing. Plast Reconstr Surg 109: 2384-2397.

Brandi ML, Collin-Osdoby P (2006) Vascular biology and the skeleton. J Bone Miner Res 21: 183-192.

Brandi ML, Crescioli C, Tanini A, Frediani U, Agnusdei D, Gennari C (1993) Bone endothelial cells as estrogen targets. Calcif Tissue Int 53: 312-317.

Bucay N, Sarosi I, Dunstan CR, Morony S, Tarpley J, Capparelli C, Scully S, Tan HL, Xu W, Lacey DL, Boyle WJ, Simonet WS (1998) osteoprotegerin-deficient mice develop early onset osteoporosis and arterial calcification. Genes Dev 12: 1260-1268.

Burkhardt R, Kettner G, Bohm W, Schmidmeier M, Schlag R, Frisch B, Mallmann B, Eisenmenger W, Gilg T (1987) Changes in trabecular bone, hematopoiesis and bone marrow vessels in aplastic anemia, primary osteoporosis, and old age: a comparative histomorphometric study. Bone 8: 157-164.

Burkus JK, Ganey TM, Ogden JA (1993) Development of the cartilage canals and the secondary center of ossification in the distal chondroepiphysis of the prenatal human femur. Yale J Biol Med 66: 193-202.

Carano RA, Filvaroff EH (2003) Angiogenesis and bone repair. Drug Discov Today 8: 980-989.

Carlevaro MF, Cermelli S, Cancedda R, Descalzi CF (2000) Vascular endothelial growth factor (VEGF) in cartilage neovascularization and chondrocyte differentiation: auto-paracrine role during endochondral bone formation. J Cell Sci 113: 59-69.

Carmeliet P, Collen D (2000) Molecular basis of angiogenesis. Role of VEGF and VE-cadherin. Ann N Y Acad Sci 902: 249-262.

Carmeliet P (2003) Angiogenesis in health and disease. Nat Med 9: 653-660.
Chang PC, Liu BY, Liu CM, Chou HH, Ho MH, Liu HC, Wang DM, Hou LT (2007) Bone tissue engineering with novel rhBMP2-PLLA composite scaffolds. J Biomed Mater Res A 81: 771-780.

Chen WJ, Jingushi S, Aoyama I, Anzai J, Hirata G, Tamura M, Iwamoto Y (2004) Effects of FGF-2 on metaphyseal fracture repair in rabbit tibiae. J Bone Miner Metab 22: 303-309.

Cheung C (2005) The future of bone healing. Clin Podiatr Med Surg 22: 631-641.

Childs SG (2005) Osteonecrosis: death of bone cells. Orthop Nurs 24: 295-301.

Chu TM, Warden SJ, Turner CH, Stewart RL (2007) Segmental bone regeneration using a load-bearing biodegradable carrier of bone morphogenetic protein-2. Biomaterials 28: 459-467.

Chu TW, Wang ZG, Zhu PF, Jiao WC, Wen JL, Gong SG (2002) [Effect of vascular endothelial growth factor in fracture healing]. Zhongguo Xiu Fu Chong Jian Wai Ke Za Zhi 16: 75-78.

Clemens TL (1996) Vasoactive Agents and Bone metabolism. In: Principles of Bone Biology. Bilezekian JP, Raisz LG, Rodan GA(eds). Academic Press, San Diego. pp. 597-605.

Coffin JD, Florkiewicz RZ, Neumann J, Mort-Hopkins T, Dorn GW, Lightfoot P, German R, Howles PN, Kier A, O'Toole BA (1995) Abnormal bone growth and selective translational regulation in basic fibroblast growth factor (FGF-2) transgenic mice. Mol Biol Cell 6: 1861-1873.

Collin-Osdoby P (1994) Role of vascular endothelial cells in bone biology. J Cell Biochem 55: 304-309.

Collin-Osdoby P, Rothe L, Anderson F, Nelson M, Maloney W, Osdoby P (2001) Receptor activator of NFkappa $\mathrm{B}$ and osteoprotegerin expression by human microvascular endothelial cells, regulation by inflammatory cytokines, and role in human osteoclastogenesis. J Biol Chem 276: 20659-20672.

Collin-Osdoby P, Rothe L, Bekker S, Anderson F, Huang Y, Osdoby P (2002) Basic fibroblast growth factor stimulates osteoclast recruitment, development, and bone pit resorption in association with angiogenesis in vivo on the chick chorioallantoic membrane and activates isolated avian osteoclast resorption in vitro. J Bone Miner Res 17: 1859-1871.

Colnot C, Romero DM, Huang S, Helms JA (2005) Mechanisms of action of demineralized bone matrix in the repair of cortical bone defects. Clin Orthop Relat Res 435: 69-78.

Colton CK (1995) Implantable biohybrid artificial organs. Cell Transplant 4: 415-436.

Coultas L, Chawengsaksophak K, Rossant J (2005) Endothelial cells and VEGF in vascular development. Nature 438: 937-945.

Deckers MM, Karperien M, van der Bent C, Yamashita T, Papapoulos SE, Lowik CW (2000) Expression of vascular endothelial growth factors and their receptors during osteoblast differentiation. Endocrinology 141: 1667-1674.

Deckers MM, van Bezooijen RL, van der Horst G, Hoogendam J, van der Bent C, Papapoulos SE, Lowik CW (2002) Bone morphogenetic proteins stimulate 
angiogenesis through osteoblast-derived vascular endothelial growth factor A. Endocrinology 143: 1545 1553.

Domaschke H, Gelinsky M, Burmeister B, Fleig R, Hanke T, Reinstorf A, Pompe W, Rosen-Wolff A (2006) In vitro ossification and remodeling of mineralized collagen I scaffolds. Tissue Eng 12: 949-958.

Engsig MT, Chen QJ, Vu TH, Pedersen AC, Therkidsen B, Lund LR, Henriksen K, Lenhard T, Foged NT, Werb Z, Delaisse JM (2000) Matrix metalloproteinase 9 and vascular endothelial growth factor are essential for osteoclast recruitment into developing long bones. J Cell Biol 151: 879-889.

Erlebacher A, Filvaroff EH, Ye JQ, Derynck R (1998) Osteoblastic responses to TGF-beta during bone remodeling. Mol Biol Cell 9: 1903-1918.

Ferrara N, Gerber HP (2001) The role of vascular endothelial growth factor in angiogenesis. Acta Haematol 106: $148-156$.

Ferrara N, Gerber HP, LeCouter J (2003) The biology of VEGF and its receptors. Nat Med 9: 669-676.

Findlay DM, Haynes DR (2005) Mechanisms of bone loss in rheumatoid arthritis. Mod Rheumatol 15: 232-240.

Geiger F, Bertram H, Berger I, Lorenz H, Wall O, Eckhardt C, Simank HG, Richter W (2005) Vascular endothelial growth factor gene-activated matrix (VEGF165-GAM) enhances osteogenesis and angiogenesis in large segmental bone defects. J Bone Miner Res 20: 2028-2035.

Georgiou G, Mathieu L, Pioletti DP, Bourban PE, Manson JA, Knowles JC, Nazhat SN (2007) Polylactic acid-phosphate glass composite foams as scaffolds for bone tissue engineering. J Biomed Mater Res B Appl Biomater 80: $322-331$.

Gerber HP, Ferrara N (2000) Angiogenesis and bone growth. Trends Cardiovasc Med 10: 223-228.

Gerber HP, Vu TH, Ryan AM, Kowalski J, Werb Z, Ferrara N (1999) VEGF couples hypertrophic cartilage remodeling, ossification and angiogenesis during endochondral bone formation. Nat Med 5: 623-628.

Globus RK, Patterson-Buckendahl P, Gospodarowicz D (1988) Regulation of bovine bone cell proliferation by fibroblast growth factor and transforming growth factor beta. Endocrinology 123: 98-105.

Glowacki J (1998) Angiogenesis in fracture repair. Clin Orthop Relat Res 355S: S82-S89.

Haigh JJ, Gerber HP, Ferrara N, Wagner EF (2000) Conditional inactivation of VEGF-A in areas of collagen2a1 expression results in embryonic lethality in the heterozygous state. Development 127: 1445-1453.

Hall AP, Westwood FR, Wadsworth PF (2006) Review of the effects of anti-angiogenic compounds on the epiphyseal growth plate. Toxicol Pathol 34: 131-147.

Haller A (1763) Experimentorum de ossiem formatione. 2: 400 Francisci Grasset.

Hayami T, Funaki H, Yaoeda K, Mitui K, Yamagiwa H, Tokunaga K, Hatano H, Kondo J, Hiraki Y, Yamamoto T, Duong IT, Endo N (2003) Expression of the cartilage derived anti-angiogenic factor chondromodulin-I decreases in the early stage of experimental osteoarthritis. J Rheumatol 30: 2207-2217.
Hayashi K (1992) Three-dimensional organization of the cartilage canal-a scanning electron-microscopic study by vascular cast of the rabbit's femoral head. Nippon Seikeigeka Gakkai Zasshi 66: 548-559.

Hayek A, Culler FL, Beattie GM, Lopez AD, Cuevas P, Baird A (1987) An in vivo model for study of the angiogenic effects of basic fibroblast growth factor. Biochem Biophys Res Commun 147: 876-880.

Horner A, Bishop NJ, Bord S, Beeton C, Kelsall AW, Coleman N, Compston JE (1999) Immunolocalisation of vascular endothelial growth factor (VEGF) in human neonatal growth plate cartilage. J Anat 194: 519-524.

Hou LT, Liu CM, Liu BY, Chang PC, Chen MH, Ho MH, Jehng SM, Liu HC (2007) Tissue engineering bone formation in novel recombinant human bone morphogenic protein 2-atelocollagen composite scaffolds. J Periodontol 78: 335-343.

Horton WA (1990) The biology of bone growth. Growth Genet Horm 6: 1-3.

Huang YC, Kaigler D, Rice KG, Krebsbach PH, Mooney DJ (2005) Combined angiogenic and osteogenic factor delivery enhances bone marrow stromal cell-driven bone regeneration. J Bone Miner Res 20: 848-857.

Huang YC, Simmons C, Kaigler D, Rice KG, Mooney DJ (2005) Bone regeneration in a rat cranial defect with delivery of PEI-condensed plasmid DNA encoding for bone morphogenetic protein-4 (BMP-4). Gene Ther 12: 418-426.

Hunter J (1794) Treatise on the Blood, Inflammation and Gunshot Wounds. Eds George Nicol. London.

Hunziker EB (1994) Mechanism of longitudinal bone growth and its regulation by growth plate chondrocytes. Microsc Res Tech 28: 505-519.

Imai K, Kobayashi M, Wang J, Shinobu N, Yoshida H, Hamada J, Shindo M, Higashino F, Tanaka J, Asaka M, Hosokawa M (1999) Selective secretion of chemoattractants for haemopoietic progenitor cells by bone marrow endothelial cells: a possible role in homing of haemopoietic progenitor cells to bone marrow. Br J Haematol 106: 905-911.

Imhof BA, Dunon D (1997) Basic mechanism of leukocyte migration. Horm Metab Res 29: 614-621.

Inui K, Maeda M, Sano A, Fujioka K, Yutani Y, Sakawa A, Yamano Y, Kato Y, Koike T (1998) Local application of basic fibroblast growth factor minipellet induces the healing of segmental bony defects in rabbits. Calcif Tissue Int 63: 490-495.

Ivkovic S, Yoon BS, Popoff SN, Safadi FF, Libuda DE, Stephenson RC, Daluiski A, Lyons KM (2003) Connective tissue growth factor coordinates chondrogenesis and angiogenesis during skeletal development. Development 130: 2779-2791.

Iyama K, Ninomiya Y, Olsen BR, Linsenmayer TF, Trelstad RL, Hayashi M (1991) Spatiotemporal pattern of type $\mathrm{X}$ collagen gene expression and collagen deposition in embryonic chick vertebrae undergoing endochondral ossification. Anat Rec 229: 462-472.

Jain RK (2003) Molecular regulation of vessel maturation. Nat Med 9: 685-693.

Jansen JA, Vehof JW, Ruhe PQ, Kroeze-Deutman H, Kuboki Y, Takita H, Hedberg EL, Mikos AG (2005) 
Growth factor-loaded scaffolds for bone engineering. J Control Release 101: 127-136.

Jeon O, Song SJ, Kang SW, Putnam AJ, Kim BS (2007) Enhancement of ectopic bone formation by bone morphogenetic protein-2 released from a heparinconjugated poly(L-lactic-co-glycolic acid) scaffold. Biomaterials 28: 2763-2771.

Johnell O (1997) The socioeconomic burden of fractures: today and in the 21st century. Am J Med 103: 20S-25S.

Kaigler D, Wang Z, Horger K, Mooney DJ, Krebsbach PH (2006a) VEGF scaffolds enhance angiogenesis and bone regeneration in irradiated osseous defects. J Bone Miner Res 21: 735-744.

Kaigler D, Krebsbach PH, Wang Z, West ER, Horger K, Mooney DJ (2006b). Transplanted endothelial cells enhance orthotopic bone regeneration. J Dent Res 85: 633637.

Kanczler JM, Millar TM, Bodamyali T, Blake DR, Stevens CR (2003) Xanthine oxidase mediates cytokineinduced, but not hormone-induced bone resorption. Free Radic Res 37: 179-187.

Kanczler JM, Barry J, Ginty P, Howdle SM, Shakesheff KM, Oreffo RO (2007) Supercritical carbon dioxide generated vascular endothelial growth factor encapsulated poly(DL-lactic acid) scaffolds induce angiogenesis in vitro. Biochem Biophys Res Commun 352: 135-141.

Kawaguchi H, Kurokawa T, Hanada K, Hiyama Y, Tamura M, Ogata E, Matsumoto T (1994) Stimulation of fracture repair by recombinant human basic fibroblast growth factor in normal and streptozotocin-diabetic rats. Endocrinology 135: 774-781.

Kawaguchi H, Nakamura K, Tabata Y, Ikada Y, Aoyama I, Anzai J, Nakamura T, Hiyama Y, Tamura M (2001) Acceleration of fracture healing in nonhuman primates by fibroblast growth factor-2. J Clin Endocrinol Metab 86: 875-880.

Khan YM, Katti DS, Laurencin CT (2004) Novel polymer-synthesized ceramic composite-based system for bone repair: an in vitro evaluation. J Biomed Mater Res A 69: 728-737.

Kloen P, Di PM, Borens O, Richmond J, Perino G, Helfet DL, Goumans MJ (2003) BMP signaling components are expressed in human fracture callus. Bone 33: $362-371$

Koike N, Fukumura D, Gralla O, Au P, Schechner JS, Jain RK (2004)Tissue engineering: creation of long-lasting blood vessels. Nature 428: 138-139.

Kronenberg HM (2003) Developmental regulation of the growth plate. Nature 423: 332-336.

Kugler JH, Tomlinson A, Wagstaff A, Ward SM (1979) The role of cartilage canals in the formation of secondary centres of ossification. J Anat 129: 493-506.

Lazzarini L, De Lalla F, Mader JT (2002) Long Bone Osteomyelitis. Curr Infect Dis Rep 4: 439-445.

Leach JK, Kaigler D, Wang Z, Krebsbach PH, Mooney DJ (2006) Coating of VEGF-releasing scaffolds with bioactive glass for angiogenesis and bone regeneration. Biomaterials 27: 3249-3255.

Levenberg S, Rouwkema J, Macdonald M, Garfein ES, Kohane DS, Darland DC, Marini R, van Blitterswijk CA,
Mulligan RC, D’Amore PA, Langer R (2005) Engineering vascularized skeletal muscle tissue. Nat Biotechnol 23: 879-884.

Li WJ, Tuli R, Huang X, Laquerriere P, Tuan RS (2005) Multilineage differentiation of human mesenchymal stem cells in a three-dimensional nanofibrous scaffold. Biomaterials 26: 5158-5166.

Logeart-Avramoglou D, Anagnostou F, Bizios R, Petite $\mathrm{H}$ (2005) Engineering bone: challenges and obstacles. J Cell Mol Med 9: 72-84.

Lu Q, Ganesan K, Simionescu DT, Vyavahare NR (2004) Novel porous aortic elastin and collagen scaffolds for tissue engineering. Biomaterials 25: 5227-5237.

Lubiatowski P, Kruczynski J, Gradys A, Trzeciak T, Jaroszewski J (2006) Articular cartilage repair by means of biodegradable scaffolds. Transplant Proc 38: 320-322.

Madeddu P (2005) Therapeutic angiogenesis and vasculogenesis for tissue regeneration. Exp Physiol 90: 315-326.

Maes C, Carmeliet P, Moermans K, Stockmans I, Smets N, Collen D, Bouillon R, Carmeliet G (2002) Impaired angiogenesis and endochondral bone formation in mice lacking the vascular endothelial growth factor isoforms VEGF164 and VEGF188. Mech Dev 111: 61-73.

Mandracchia VJ, Nelson SC, Barp EA (2001) Current concepts of bone healing. Clin Podiatr Med Surg 18: 5577.

Marks SC, Hermey DC (1996) The Structure and Development of Bone. In: Principles of Bone Biology. Bilezekian JP, Raisz LG, Rodan GA (eds). Academic Press, SanDiego. pp. 3-24.

Marotti G, Zallone AZ (1980) Changes in the vascular network during the formation of Haversian systems. Acta Anat (Basel) 106: 84-100.

Meury T, Verrier S, Alini M (2006) Human endothelial cells inhibit BMSC differentiation into mature osteoblasts in vitro by interfering with osterix expression. J Cell Biochem 98: 992-1006.

Midy V, Plouët J (1994) Vasculotropin/vascular endothelial growth factor induces differentiation in cultured osteoblasts. Biochem Biophys Res Commun 199: 380-386.

Montero A, Okada Y, Tomita M, Ito M, Tsurukami H, Nakamura T, Doetschman T, Coffin JD, Hurley MM (2000) Disruption of the fibroblast growth factor-2 gene results in decreased bone mass and bone formation. J Clin Invest 105: 1085-1093.

Montesano R, Vassalli JD, Baird A, Guillemin R, Orci L (1986) Basic fibroblast growth factor induces angiogenesis in vitro. Proc Natl Acad Sci U S A 83: $7297-$ 7301.

Montjovent MO, Mathieu L, Hinz B, Applegate LL, Bourban PE, Zambelli PY, Manson JA, Pioletti DP (2005) Biocompatibility of bioresorbable poly(L-lactic acid) composite scaffolds obtained by supercritical gas foaming with human fetal bone cells. Tissue Eng 11: 1640-1649.

Montjovent MO, Mathieu L, Schmoekel H, Mark S, Bourban PE, Zambelli PY, Laurent-Applegate LA, Pioletti DP (2007) Repair of critical size defects in the rat cranium using ceramic-reinforced PLA scaffolds obtained by supercritical gas foaming. J Biomed Mater Res A 83: 4151. 
Moses MA, Sudhalter J, Langer R (1990) Identification of an inhibitor of neovascularization from cartilage. Science 248: 1408-1410.

Murphy WL, Peters MC, Kohn DH, Mooney DJ (2000) Sustained release of vascular endothelial growth factor from mineralized poly(lactide-co-glycolide) scaffolds for tissue engineering. Biomaterials 21: 2521-2527.

Murphy WL, Simmons CA, Kaigler D, Mooney DJ (2004) Bone regeneration via a mineral substrate and induced angiogenesis. J Dent Res 83: 204-210.

Nagai H, Aoki M (2002) Inhibition of growth plate angiogenesis and endochondral ossification with diminished expression of MMP-13 in hypertrophic chondrocytes in FGF-2-treated rats. J Bone Miner Metab 20: 142-147.

Nakagawa M, Kaneda T, Arakawa T, Morita S, Sato T, Yomada T, Hanada K, Kumegawa M, Hakeda Y (2000) Vascular endothelial growth factor (VEGF) directly enhances osteoclastic bone resorption and survival of mature osteoclasts. FEBS Lett 473: 161-164.

Nakamura K, Kawaguchi H, Aoyama I, Hanada K, Hiyama Y, Awa T, Tamura M, Kurokawa T (1997) Stimulation of bone formation by intraosseous application of recombinant basic fibroblast growth factor in normal and ovariectomized rabbits. J Orthop Res 15: 307-313.

Nakamura T, Hanada K, Tamura M, Shibanushi T, Nigi H, Tagawa M, Fukumoto S, Matsumoto T (1995) Stimulation of endosteal bone formation by systemic injections of recombinant basic fibroblast growth factor in rats. Endocrinology 136: 1276-1284.

Netelenbos T, Drager AM, van het Hof B, Kessler FL, Delouis C, Huijgens PC, van den Born J, van Dijk W (2001) Differences in sulfation patterns of heparan sulfate derived from human bone marrow and umbilical vein endothelial cells. Exp Hematol 29: 884-893.

Niida S, Kaku M, Amano H, Yoshida H, Kataoka H, Nishikawa S, Tanne K, Maeda N, Nishikawa S, Kodama H (1999) Vascular endothelial growth factor can substitute for macrophage colony-stimulating factor in the support of osteoclastic bone resorption. J Exp Med 190: 293-298.

Nikolova G, Strilic B, Lammert E (2006) The vascular niche and its basement membrane. Trends Cell Biol 17: 19-25.

Oest ME, Dupont KM, Kong HJ, Mooney DJ, Guldberg RE (2007) Quantitative assessment of scaffold and growth factor-mediated repair of critically sized bone defects. J Orthop Res 25: 941-950.

Oreffo RO, Triffitt JT (1999) Future potentials for using osteogenic stem cells and biomaterials in orthopedics. Bone 25(2suppl): 5S-9S.

Orth MW (1999) The regulation of growth plate cartilage turnover. J Anim Sci 77 Suppl 2: 183-189.

Otto F, Thornell AP, Crompton T, Denzel A, Gilmour KC, Rosewell IR, Stamp GW, Beddington RS, Mundlos S, Olsen BR, Selby PB, Owen MJ (1997) Cbfa1, a candidate gene for cleidocranial dysplasia syndrome, is essential for osteoblast differentiation and bone development. Cell 89: 765-771.

Parfitt AM (2000) The mechanism of coupling: a role for the vasculature. Bone 26: 319-323.
Peng H, Wright V, Usas A, Gearhart B, Shen HC, Cummins J, Huard J (2002) Synergistic enhancement of bone formation and healing by stem cell-expressed VEGF and bone morphogenetic protein-4. J Clin Invest 110: 751759.

Peng H, Usas A, Olshanski A, Ho AM, Gearhart B, Cooper GM, Huard J (2005) VEGF improves, whereas sFlt1 inhibits, BMP2-induced bone formation and bone healing through modulation of angiogenesis. J Bone Miner Res 20: 2017-2027.

Petersen W, Tsokos M, Pufe T (2002) Expression of VEGF121 and VEGF165 in hypertrophic chondrocytes of the human growth plate and epiphyseal cartilage. J Anat 201: 153-157.

Popov VK, Evseev AV, Ivanov AL, Roginski VV, Volozhin AI, Howdle SM (2004) Laser stereolithography and supercritical fluid processing or custom-designed implant fabrication. J Mater Sci-Mater Med 15: 123-128.

Potier E, Ferreira E, Andriamanalijaona R, Pujol JP, Oudina K, Logeart-Avramoglou D, Petite H (2007) Hypoxia affects mesenchymal stromal cell osteogenic differentiation and angiogenic factor expression. Bone 40: 1078-1087.

Potier E, Ferreira E, Meunier A, Sedel L, LogeartAvramoglou D, Petite H (2007) Prolonged hypoxia concomitant with serum deprivation induces massive human mesenchymal stem cell death. Tissue Eng 13: 13251331.

Praemer A, Furner S, Rice D (1992) In: Musculoskeletal conditions in the United States. American Academy of Orthopaedic Surgeons (eds.), Chicago. pp. 85-124.

Pufe T, Petersen W, Tillmann B, Mentlein R (2001) The splice variants VEGF121 and VEGF189 of the angiogenic peptide vascular endothelial growth factor are expressed in osteoarthritic cartilage. Arthritis Rheum 44: 1082-1088.

Pun S, Dearden RL, Ratkus AM, Liang H, Wronski TJ (2001) Decreased bone anabolic effect of basic fibroblast growth factor at fatty marrow sites in ovariectomized rats. Bone 28: 220-226.

Raida M, Heymann AC, Günther C, Niederwieser D (2006) Role of bone morphogenetic protein 2 in the crosstalk between endothelial progenitor cells and mesenchymal stem cells. Int J Mol Med 18:735-739.

Rhinelander FW (1974) Tibial blood supply in relation to fracture healing. Clin Orthop Relat Res 105: 34-81.

Richardson TP, Peters MC, Ennett AB, Mooney DJ (2001) Polymeric system for dual growth factor delivery. Nat Biotechnol 19: 1029-1034.

Risau W, Drexler H, Mironov V, Smits A, Siegbahn A, Funa K, Heldin CH (1992) Platelet-derived growth factor is angiogenic in vivo. Growth Factors 7: 261-266.

Rodan SB, Wesolowski G, Thomas KA, Yoon K, Rodan GA (1989) Effects of acidic and basic fibroblast growth factors on osteoblastic cells. Connect Tissue Res 20: 283288.

Rood PM, Gerritsen WR, Kramer D, Ranzijn C, von dem Borne AE, van der Schoot CE (1999) Adhesion of hematopoietic progenitor cells to human bone marrow or 
umbilical vein derived endothelial cell lines: a comparison. Exp Hematol 27: 1306-1314.

Rose FR, Hou Q, Oreffo RO (2004) Delivery systems for bone growth factors - the new players in skeletal regeneration. J Pharm Pharmacol 56: 415-427.

Rosier RN, O’Keefe RJ, Hicks DG (1998) The potential role of transforming growth factor beta in fracture healing. Clin Orthop Relat Res 355S: S294-S300.

Rossant J, Howard L (2002) Signaling pathways in vascular development. Annu Rev Cell Dev Biol 18: 541573.

Ruhe PQ, Hedberg EL, Padron NT, Spauwen PH, Jansen JA, Mikos AG (2005a) Biocompatibility and degradation of poly(DL-lactic-co-glycolic acid)/calcium phosphate cement composites. J Biomed Mater Res A 74: 533-544.

Ruhe PQ, Boerman OC, Russel FG, Spauwen PH, Mikos AG, Jansen JA (2005b) Controlled release of rhBMP-2 loaded poly(dl-lactic-co-glycolic acid)/calcium phosphate cement composites in vivo. J Control Release 106: $162-171$.

Ryan AM, Eppler DB, Hagler KE, Bruner RH, Thomford PJ, Hall RL, Shopp GM, O’Neill CA (1999) Preclinical safety evaluation of rhuMAbVEGF, an antiangiogenic humanized monoclonal antibody. Toxicol Pathol 27: 78-86.

Sachlos E, Czernuszka JT (2003) Making tissue engineering scaffolds work. Review: the application of solid freeform fabrication technology to the production of tissue engineering scaffolds. Eur Cell Mater 5: 29-39.

Saijo M, Kitazawa R, Nakajima M, Kurosaka M, Maeda S, Kitazawa S (2003) Heparanase mRNA expression during fracture repair in mice. Histochem Cell Biol 120: 493-503.

Salim A, Nacamuli RP, Morgan EF, Giaccia AJ, Longaker MT (2004) Transient changes in oxygen tension inhibit osteogenic differentiation and Runx2 expression in osteoblasts. J Biol Chem 279: 40007-40016.

Schechner JS, Nath AK, Zheng L, Kluger MS, Hughes CC, Sierra-Honigmann MR, Lorber MI, Tellides G, Kashgarian M, Bothwell AL, Pober JS (2000) In vivo formation of complex microvessels lined by human endothelial cells in an immunodeficient mouse. Proc Natl Acad Sci U S A 97: 9191-9196.

Schmid J, Wallkamm B, Hammerle CH, Gogolewski S, Lang NP (1997) The significance of angiogenesis in guided bone regeneration. A case report of a rabbit experiment. Clin Oral Implants Res 8: 244-248.

Schwartz Z, Goultschin J, Dean DD, Boyan BD (1997) Mechanisms of alveolar bone destruction in periodontitis. Periodontol 2000 14: 158-172.

Simonet WS, Lacey DL, Dunstan CR, Kelley M, Chang MS, Lüthy R, Nguyen HQ, Wooden S, Bennett L, Boone T, Shimamoto G, DeRose M, Elliott R, Colombero A, Tan HL, Trail G, Sullivan J, Davy E, Bucay N, Renshaw-Gegg L, Hughes TM, Hill D, Pattison W, Campbell P, Sander S, Van G, Tarpley J, Derby P, Lee R, Boyle WJ (1997) Osteoprotegerin: A Novel Secreted Protein Involved in the Regulation of Bone Density. Cell 89: 309-319.
Simons M, Bonow RO, Chronos NA, Cohen DJ, Giordano FJ, Hammond HK, Laham RJ, Li W, Pike M, Sellke FW, Stegmann TJ, Udelson JE, Rosengart TK (2000) Clinical trials in coronary angiogenesis: issues, problems, consensus: An expert panel summary. Circulation 102: E73-E86.

Sojo K, Sawaki Y, Hattori H, Mizutani H, Ueda M (2005) Immunohistochemical study of vascular endothelial growth factor (VEGF) and bone morphogenetic protein2,-4(BMP-2,-4) on lengthened rat femurs. J Craniomaxillofac Surg 33: 238-245.

Sorescu GP, Sykes M, Weiss D, Platt MO, Saha A, Hwang J, Boyd N, Boo YC, Vega JD, Taylor WR, Jo H (2003) Bone morphogenic protein 4 produced in endothelial cells by oscillatory shear stress stimulates an inflammatory response. J Biol Chem 278: 31128-31135.

Storkebaum E, Carmeliet P (2004) VEGF: a critical player in neurodegeneration. J Clin Invest 113: 14-18.

Street J, Winter D, Wang JH, Wakai A, McGuinness A, Redmond HP (2000) Is human fracture hematoma inherently angiogenic? Clin Orthop Relat Res 378: 224237.

Street J, Bao M, deGuzman L, Bunting S, Peale FV, Jr., Ferrara N, Steinmetz H, Hoeffel J, Cleland JL, Daugherty A, van BN, Redmond HP, Carano RA, Filvaroff EH (2002) Vascular endothelial growth factor stimulates bone repair by promoting angiogenesis and bone turnover. Proc Natl Acad Sci U S A 99: 9656-9661.

Streeten EA, Ornberg R, Curcio F, Sakaguchi K, Marx S, Aurbach GD, Brandi ML (1989) Cloned endothelial cells from fetal bovine bone. Proc Natl Acad Sci U S A 86: 916-920.

Streeten EA, Brandi ML (1990) Biology of bone endothelial cells. Bone Miner 10: 85-94.

Sugiyama T, Kohara H, Noda M, Nagasawa T (2006) Maintenance of the hematopoietic stem cell pool by CXCL12-CXCR4 chemokine signaling in bone marrow stromal cell niches. Immunity 25: 977-988.

Sutherland RM, Sordat B, Bamat J, Gabbert H, Bourrat B, Mueller-Klieser W (1986) Oxygenation and differentiation in multicellular spheroids of human colon carcinoma. Cancer Res 46: 5320-5329.

Tai H, Popov VK, Shakesheff KM, Howdle SM (2007) Putting the fizz into chemistry: applications of supercritical carbon dioxide in tissue engineering, drug delivery and synthesis of novel block copolymers. Biochem Soc Trans 35: 516-521.

Taichman RS, Cooper C, Keller ET, Pienta KJ, Taichman NS, McCauley LK (2002) Use of the stromal cell-derived factor-1/CXCR4 pathway in prostate cancer metastasis to bone. Cancer Res 62: 1832-1837.

Takeshita S, Zheng LP, Brogi E, Kearney M, Pu LQ, Bunting S, Ferrara N, Symes JF, Isner JM (1994) Therapeutic angiogenesis. A single intraarterial bolus of vascular endothelial growth factor augments revascularization in a rabbit ischemic hind limb model. J Clin Invest 93: 662-670.

Tammela T, Enholm B, Alitalo K, Paavonen K (2005) The biology of vascular endothelial growth factors. Cardiovasc Res 65: 550-563. 
Tatsuyama K, Maezawa Y, Baba H, Imamura Y, Fukuda M (2000) Expression of various growth factors for cell proliferation and cytodifferentiation during fracture repair of bone. Eur J Histochem 44: 269-278.

Trueta J (1963) The role of the vessels in osteogenesis. Journal of Bone and Joint Surgery Series A 45B: 402-418.

Uchida S, Sakai A, Kudo H, Otomo H, Watanuki M, Tanaka M, Nagashima M, Nakamura T (2003) Vascular endothelial growth factor is expressed along with its receptors during the healing process of bone and bone marrow after drill-hole injury in rats. Bone 32: 491-501.

Väänänen HK (1980) Immunohistochemical localization of alkaline phosphatase in the chicken epiphyseal growth cartilage. Histochemistry 65: 143-148.

Villars F, Bordenave L, Bareille R, Amedee J (2000) Effect of human endothelial cells on human bone marrow stromal cell phenotype: role of VEGF? J Cell Biochem 79: 672-685.

Villars F, Guillotin B, Amedee T, Dutoya S, Bordenave L, Bareille R, Amedee J (2002) Effect of HUVEC on human osteoprogenitor cell differentiation needs heterotypic gap junction communication. Am J Physiol Cell Physiol 282: C775-C785.

Visco DM, Van S, Hill MA, Kincaid SA (1989) The vascular supply of the chondro-epiphyses of the elbow joint in young swine. J Anat 163: 215-229.

Vogelin E, Jones NF, Huang JI, Brekke JH, Lieberman JR (2005) Healing of a critical-sized defect in the rat femur with use of a vascularized periosteal flap, a biodegradable matrix, and bone morphogenetic protein. J Bone Joint Surg Am 87: 1323-1331.

Vu TH, Shipley JM, Bergers G, Berger JE, Helms JA, Hanahan D, Shapiro SD, Senior RM, Werb Z (1998) MMP9/gelatinase B is a key regulator of growth plate angiogenesis and apoptosis of hypertrophic chondrocytes. Cell 93: 411-422.

Walsh DA, Mapp PI (1998) Joint physiology and synovial cell proliferation. Br J Rheumatol 37: 1032-1033.

Walsh S, Jefferiss C, Stewart K, Jordan GR, Screen J, Beresford JN (2000) Expression of the developmental markers STRO-1 and alkaline phosphatase in cultures of human marrow stromal cells: regulation by fibroblast growth factor (FGF)-2 and relationship to the expression of FGF receptors 1-4. Bone 27: 185-195.

Wang Y, Wan C, Deng L, Liu X, Cao X, Gilbert SR, Bouxsein ML, Faugere MC, Guldberg RE, Gerstenfeld LC, Haase VH, Johnson RS, Schipani E, Clemens TL (2007) The hypoxia-inducible factor alpha pathway couples angiogenesis to osteogenesis during skeletal development. J Clin Invest 117: 1616-1626.

Wedge SR, Ogilvie DJ, Dukes M, Kendrew J, Chester R, Jackson JA, Boffey SJ, Valentine PJ, Curwen JO, Musgrove HL, Graham GA, Hughes GD, Thomas AP, Stokes ES, Curry B, Richmond GH, Wadsworth PF, Bigley AL, Hennequin LF (2002) ZD6474 inhibits vascular endothelial growth factor signaling, angiogenesis, and tumor growth following oral administration. Cancer Res 62: 4645-4655.

Wei G, Ma PX (2004) Structure and properties of nanohydroxyapatite/polymer composite scaffolds for bone tissue engineering. Biomaterials 25: 4749-4757.

Wei G, Jin Q, Giannobile WV, Ma PX (2007) The enhancement of osteogenesis by nano-fibrous scaffolds incorporating rhBMP-7 nanospheres. Biomaterials 28: 2087-2096.

Yabsley RH, Harris WR (1965) The Effect of Shaft Fractures and Periosteal Stripping on the Vascular Supply to Epiphyseal Plates. J Bone Joint Surg Am. 47: 551-566.

Yancopoulos GD, Davis S, Gale NW, Rudge JS, Wiegand SJ, Holash J (2000) Vascular-specific growth factors and blood vessel formation. Nature 407: 242-248.

Yang J, Nagavarapu U, Relloma K, Sjaastad MD, Moss WC, Passaniti A, Herron GS (2001) Telomerized human microvasculature is functional in vivo. Nat Biotechnol 19: 219-224.

Yang XB, Whitaker MJ, Sebald W, Clarke N, Howdle SM, Shakesheff KM, Oreffo RO (2004) Human osteoprogenitor bone formation using encapsulated bone morphogenetic protein 2 in porous polymer scaffolds. Tissue Eng 10: 1037-1045.

Yao Z, Lafage-Proust MH, Plouet J, Bloomfield S, Alexandre C, Vico L (2004) Increase of both angiogenesis and bone mass in response to exercise depends on VEGF. J Bone Miner Res 19: 1471-1480.

Yoshida H, Hayashi S, Kunisada T, Ogawa M, Nishikawa S, Okamura H, Sudo T, Shultz LD, Nishikawa $\mathrm{S}$ (1990) The murine mutation osteopetrosis is in the coding region of the macrophage colony stimulating factor gene. Nature 345: 442-444.

Ytrehus B, Carlson CS, Lundeheim N, Mathisen L, Reinholt FP, Teige J, Ekman S (2004) Vascularisation and osteochondrosis of the epiphyseal growth cartilage of the distal femur in pigs-development with age, growth rate, weight and joint shape. Bone 34: 454-465.

Zannettino AC, Holding CA, Diamond P, Atkins GJ, Kostakis P, Farrugia A, Gamble J, To LB, Findlay DM, Haynes DR (2005) Osteoprotegerin (OPG) is localized to the Weibel-Palade bodies of human vascular endothelial cells and is physically associated with von Willebrand factor. J Cell Physiol 204: 714-723.

Zelzer E, McLean W, Ng YS, Fukai N, Reginato AM, Lovejoy S, D'Amore PA, Olsen BR (2002) Skeletal defects in VEGF(120/120) mice reveal multiple roles for VEGF in skeletogenesis. Development 129: 1893-1904.

Zheng H, Yu X, Collin-Osdoby P, Osdoby P (2006) RANKL stimulates inducible nitric-oxide synthase expression and nitric oxide production in developing osteoclasts. An autocrine negative feedback mechanism triggered by RANKL-induced interferon-beta via NFkappaB that restrains osteoclastogenesis and bone resorption. J Biol Chem 281: 15809-15820. 